\title{
Desmozoon lepeophtherii n. gen., n. sp., (Microsporidia: Enterocytozoonidae) infecting the salmon louse Lepeophtheirus salmonis (Copepoda: Caligidae)
} Mark A Freeman ${ }^{* \dagger 1,2}$ and Christina Sommerville ${ }^{\dagger 1}$

\author{
Address: ${ }^{1}$ Institute of Aquaculture, University of Stirling, Stirling, FK9 4LA, UK and ${ }^{2}$ Institute of Earth and Ocean Sciences, University of Malaya, \\ Kuala Lumpur, 50603, Malaysia \\ Email: Mark A Freeman* - mark@um.edu.my; Christina Sommerville - cs3@stir.ac.uk \\ ${ }^{*}$ Corresponding author †Equal contributors
}

Published: 27 November 2009

Parasites \& Vectors 2009, 2:58 doi:10.1186/1756-3305-2-58
Received: I November 2009

Accepted: 27 November 2009

This article is available from: http://www.parasitesandvectors.com/content/2/1/58

(C) 2009 Freeman and Sommerville; licensee BioMed Central Ltd.

This is an Open Access article distributed under the terms of the Creative Commons Attribution License (http://creativecommons.org/licenses/by/2.0), which permits unrestricted use, distribution, and reproduction in any medium, provided the original work is properly cited.

\begin{abstract}
Background: A microsporidian was previously reported to infect the crustacean parasite, Lepeophtheirus salmonis (Krøyer, 1837) (Copepoda, Caligidae), on farmed Atlantic salmon (Salmo salar L.) in Scotland. The microsporidian was shown to be a novel species with a molecular phylogenetic relationship to Nucleospora (Enterocytozoonidae), but the original report did not assign it to a genus or species. Further studies examined the development of the microsporidian in L. salmonis using electron microscopy and re-evaluated the molecular findings using new sequence data available for the group. Here we report a full description for the microsporidian and assign it to a new genus and species.

Results: The microsporidian infects subcuticular cells that lie on the innermost region of the epidermal tissue layer beneath the cuticle and along the internal haemocoelic divisions. The mature spores are sub-spherical with a single nucleus and an isofilar polar filament with 5-8 turns in a double coil. The entire development is in direct contact with the host cell cytoplasm and is polysporous. During early merogony, a diplokaryotic nuclear arrangement exists which is absent throughout the rest of the developmental cycle. Large merogonial plasmodia form which divide to form single uninucleate sporonts. Sporogonial plasmodia were not observed; instead, binucleate sporonts divide to form two sporoblasts. Prior to final division, there is a precocious development of the polar filament extrusion apparatus which is associated with large electron lucent inclusions (ELIs). Analyses of DNA sequences reveal that the microsporidian is robustly supported in a clade with other members of the Enterocytozoonidae and confirms a close phylogenetic relationship with Nucleospora.
\end{abstract}

Conclusion: The ultrastructural findings of the precocious development of the polar filament and the presence of ELIs are consistent with those of the Enterocytozoonidae. However, the confirmed presence of an early diplokaryotic stage and a merogonial plasmodium that divides to yield uninucleate sporonts instead of transforming into a sporogonial syncitium, are features not currently associated with the family. Yet, analyses of DNA sequence data clearly place the microsporidian within the Enterocytozoonidae. Therefore, due to the novelty of the copepod host, the ultrastructural findings and the robust nature of the phylogenetic analyses, a new genus should be created within the Enterocytozoonide; Desmozoon lepeophtherii n. gen. n. sp. is proposed. 


\section{Background}

Microsporidia infect a wide range of invertebrate and vertebrate taxa, and are common parasites of both fish and arthropods. Reports of microsporidian infections in marine and freshwater crustacea are also numerous and include various microsporidian genera infecting marine crabs [1-4], brine shrimp [5], cladocerans [6,7], ostracods [8], marine shrimps [9-14], amphipods [15], freshwater crayfish [16], marine lobster [17] and copepods [18-22].

Although nine genera and approximately 50 species of microsporidia have been described from copepods $[18,20,22]$, none have been described from free-living marine copepods. However, there are two reports of microsporidia as hyperparasites of parasitic marine copepods. An unidentified microsporidian, phylogenetically related to Nucleospora spp. (Enterocytozoonidae), has been reported to infect the caligid copepod Lepeophtheirus salmonis parasitic on farmed Atlantic salmon, Salmo salar $[21,23]$, and Unikaryon mytilicolae (Durfort, Vallmitjana \& Vivares, 1980) has been found infecting the cyclopoid copepod Mytilicola intestinalis (Steuer, 1902) on marine mussels [24]. A single report also exists for the hyperparasitic microsporidian, Microsporidium lamproglenae, infecting the freshwater copepod Lamproglena pulchella (von Nordmann, 1832) parasitic on the cyprinid fish, Leuciscus leuciscus L. in Europe [25].

The majority of microsporidians described from free-living freshwater copepods have complex life cycles utilising copepods as intermediate hosts and mosquito larvae as definitive hosts [26-28]. The life cycles of the microsporidians infecting parasitic marine copepods are not fully known. However, the hyperparasitic microsporidian infecting $L$. salmonis was shown experimentally not to transmit directly from copepod to copepod. Furthermore, the microsporidian DNA was isolated from internal tissues from the fish host, suggesting that the Atlantic salmon may be involved in the life cycle [23].

The microsporidian hyperparasite from L. salmonis was placed in the Enterocytozoonidae by Freeman et al. [21] based on the results of robust phylogenetic analyses, but they did not assign it to a genus. At that time, only two genera existed in the Enterocytozoonidae. Enterocytozoon, containing a single species, Enterocytozoon bieneusi (Desportes, 1985), an intestinal parasite of humans and other mammals $[29,30]$ and now known to be comprised of numerous genotypes infecting a wide range of mammals and birds [31]. The second genus, Nucleospora, is comprised of intranuclear microsporidians infecting fish [32-34]. The microsporidian from L. salmonis could not be placed in either the Enterocytozoon or the Nucleospora as the host species was too dissimilar and it was neither an intranuclear microsporidian nor one infecting intestinal ente- rocytes. In addition, the small round to sub-spherical spores of the microsporidian from L. salmonis, measuring $2.34 \times 1.83 \mu \mathrm{m}( \pm 0.01 \mu \mathrm{m})$, developing without sporophorous vesicles and forming large xenomas (up to 300 $\mu \mathrm{m}$ in diameter) in the sea lice hosts were sufficiently unique features to enable it to be distinguished from all previously described microsporidia from copepods in freshwater as well as microsporidia infecting other marine crustacea [21].

Since Freeman et al. [21] assigned the microsporidian from L. salmonis to the family Enterocytozoonidae, a new genus, Enterospora, has been created in the family for intranuclear microsporidia infecting the hepatopancreatocytes of marine decapods [4] and a new species Enterocytozoon hepatopenaei, only the second species in the genus, has been described from the cytoplasm of the tubule epithelial cells of the hepatopancreas in the black tiger shrimp Penaeus monodon (Fabricius, 1798) from Thailand [14]. Thus, the Enterocytozoonidae currently contains three genera: Enterocytozoon spp. that infect the cell cytoplasm of mammalian and bird enterocytes and tubule epithelial cells of the hepatopancreas in the black tiger shrimp, Nucleospora spp. that infect the nucleus of various fish cells and Enterospora spp. that infect the nucleus of hepatopancreatocytes in marine decapods.

In the present study we examine the ultrastructure of the microsporidian infecting L. salmonis from farmed Atlantic salmon and provide an updated molecular phylogenetic analysis. Using the combined data we describe Desmozoon lepeophtherii n. gen. n. sp., and place it in the Enterocytozoonidae as a fourth genus of the family.

\section{Methods}

Salmon lice, Lepeophtheirus salmonis, were collected from salmon farms on the West Coast of Scotland. Adult lice were carefully removed using forceps from recently culled fish during routine harvests. Specimens were transferred from the farm site to the laboratory in bags of seawater at ambient temperature and salinity. Once in the laboratory, specimens were maintained in seawater collected from the farm site, aerated at $10^{\circ} \mathrm{C}$ in $10 \mathrm{~L}$ aquaria. Daily removal of senescent and dead lice with $80 \%$ water change allowed the remaining lice to survive without their hosts for several days.

Lice were screened for the presence of microsporidian infection using a dissecting microscope. Lice with inclusions under the carapace were dissected and fresh squash preparation observed to confirm the presence of microsporidian spores using a compound microscope. Confirmed infected lice were dissected further as required and fixed in $2.5 \%$ glutaraldehyde for 2 hours, washed in cacodylate rinse buffer (0.1 M, pH 7.2) overnight. Sam- 
ples were then post-fixed in 1\% osmium tetroxide (in 1\% borax solution) for one hour, before dehydration through a graded acetone series. After dehydration to $100 \%$ acetone, the samples were transferred to a 1:1 mix of Spurr resin [35] and acetone for $1 \mathrm{hr}$ on a rotator followed by a further $2 \mathrm{hr}$ in a mix of 3:1 Spurr: acetone. Finally, the specimens were rotated for $24 \mathrm{hr}$ in $100 \%$ Spurr resin before being embedded in Beem capsules and polymerised at $60^{\circ} \mathrm{C}$ for $48 \mathrm{hrs}$.

All sections were cut using a glass knife on a Reichert Ultracut E ultramicrotome. Semi-thin sections of $1 \mu \mathrm{m}$ were first cut and visualised by staining with $1 \%$ alcian blue for $5 \mathrm{~min}$ and examined under light microscopy. Ultrathin sections $(80 \mathrm{~nm})$ were mounted on 200 mesh Formvar coated copper grids and stained with uranyl acetate and lead citrate. Ultrathin sections were examined with a Philips 301 TEM operating at $80 \mathrm{kV}$. Photographs were taken with a flat plate camera using black and white Kodak 4489 EM film.

Whole infected lice were frozen in liquid nitrogen and fractured whilst under nitrogen, by applying pressure to the carapace with a scalpel. Fractured lice were then fixed at $4{ }^{\circ} \mathrm{C}$ for one hour in $1 \%$ gluteraldehyde in $0.1 \mathrm{M}$ cacodylate buffer. This initial fixation was followed by a 23 day immersion in $3 \%$ gluteraldehyde in $0.1 \mathrm{M}$ cacodylate buffer at $4{ }^{\circ} \mathrm{C}$, followed by an over night rinse in $0.1 \mathrm{M}$ cacodylate buffer. Samples were then post-fixed in $1 \%$ osmium tetroxide (in $1 \%$ borax solution) for $2 \mathrm{hrs,}$ before dehydration through a graded ethanol series. Once in 100\% ethanol, samples were transferred to a 50:50 mix of ethanol and hexamethyldisilazane (HMDS) for $30 \mathrm{~min}$ before being transfered to 100\% HMDS for a further 30 min. Samples were air-dried at room temperature over night, mounted on aluminium stubs and coated with gold at $40 \mathrm{~mA}$ for 90s using an Edwards S150B Sputter Coater. Samples were examined using a Philips 500 scanning electron microscope operating at $15 \mathrm{kV}$. Photographs were taken using an integral camera with Ilford FP4-125 film.

Representative small subunit ribosomal DNA (SSU rDNA) sequences from the Enterocytozoonidae were used in order to view the relatedness of genera and species within the family. Sequences used are available in GenBank under the following accession numbers: Desmozoon lepeophtherii AJ431366; Enterocytozoon bieneusi L07123; Enterocytozoon bieneusi DQ793212; Enterocytozoon hepatopenaei FJ496356; Nucleospora salmonis U10883; Nucleospora salmonis AF186003; Nucleospora salmonis AF185989; Nucleospora salmonis $\underline{\mathrm{AF} 186006}$; Nucleospora sp. AF186007; Microsporidium sp. AF394528; Microsporidium sp. Fu794872. Sequences were aligned using ClustalX [36] and percentage divergence matrices constructed using the Neighbour-joining method [37]. The same alignment files were used to construct phylogenetic trees using heuristic searches and maximum parsimony in PAUP* 4.0 beta 10 [38].

In accordance with section 8.6 of the ICZN's International Code of Zoological Nomenclature, copies of this article are deposited at the following five publicly accessible libraries: Natural History Museum, London, UK; American Museum of Natural History, New York, USA; Museum National d'Histoire Naturelle, Paris, France; Russian Academy of Sciences, Moscow, Russia; Academia Sinica, Taipei, Taiwan.

\section{Results}

Fresh wet-mount preparations from dissected L. salmonis with inclusions under the carapace revealed the presence of numerous microsporidian-like spores. A definitive identification of microsporidian spores was confirmed with TEM of the infected lice. Mature spores are subspherical (round to ovoid), with a single nucleus and a thickened electron lucent endospore wall measuring between 150-250 nm thick surrounded by a thinner electron dense exospore measuring between $35-40 \mathrm{~nm}$ thick (Fig. 1a-b). The polar filament has between 5 and 8 turns, normally in a double coil, and is of the isofilar type, being of a similar diameter $(65-85 \mathrm{~nm})$ along its entire length. The mature spore has typical features of a microsporidian spore. The polar filament is attached at the anterior end of the spore via the anchoring disc, which is surrounded by the laminar structure of the polaroplast; the posterior vacuole is located at the opposite end of the spore.

SEM of freeze-fractured $L$. salmonis revealed large xenomas developing under the cuticle (Fig. 2a). The cellular surface of the epidermal layer adjacent to the cuticle is smooth and uninfected, whilst the inner most sub-cuticular epidermal region adjoining the haemocoel that contains the xenoma, has a coarse and pitted appearance (Fig. 2a). A semi-thin abdominal histological section shows xenomas forming from the innermost surface of the epidermal layer beneath the cuticle and also from the structures separating the haemal sinuses in the haemocoel (Fig. 2b). The cells in this region consist mainly of desmocytes, fibrocytes and tissue-dwelling haemocytes. The exact host cell type was undistunguishable owing to the changes effected during xenoma formation. However, the microsporidian appears to infect cells that are associated with a glycocalyx-like border on the innermost part of the epidermal layer bordering the haemocoel and along haemocoelic divisions between sinuses. TEM confirms that infection was not observed throughout the epidermal layer and is restricted to the innermost surface (Fig. 3a).

Occasional host cell remnants could be seen in large xenomas but smaller xenomas contained multiple nuclei, 

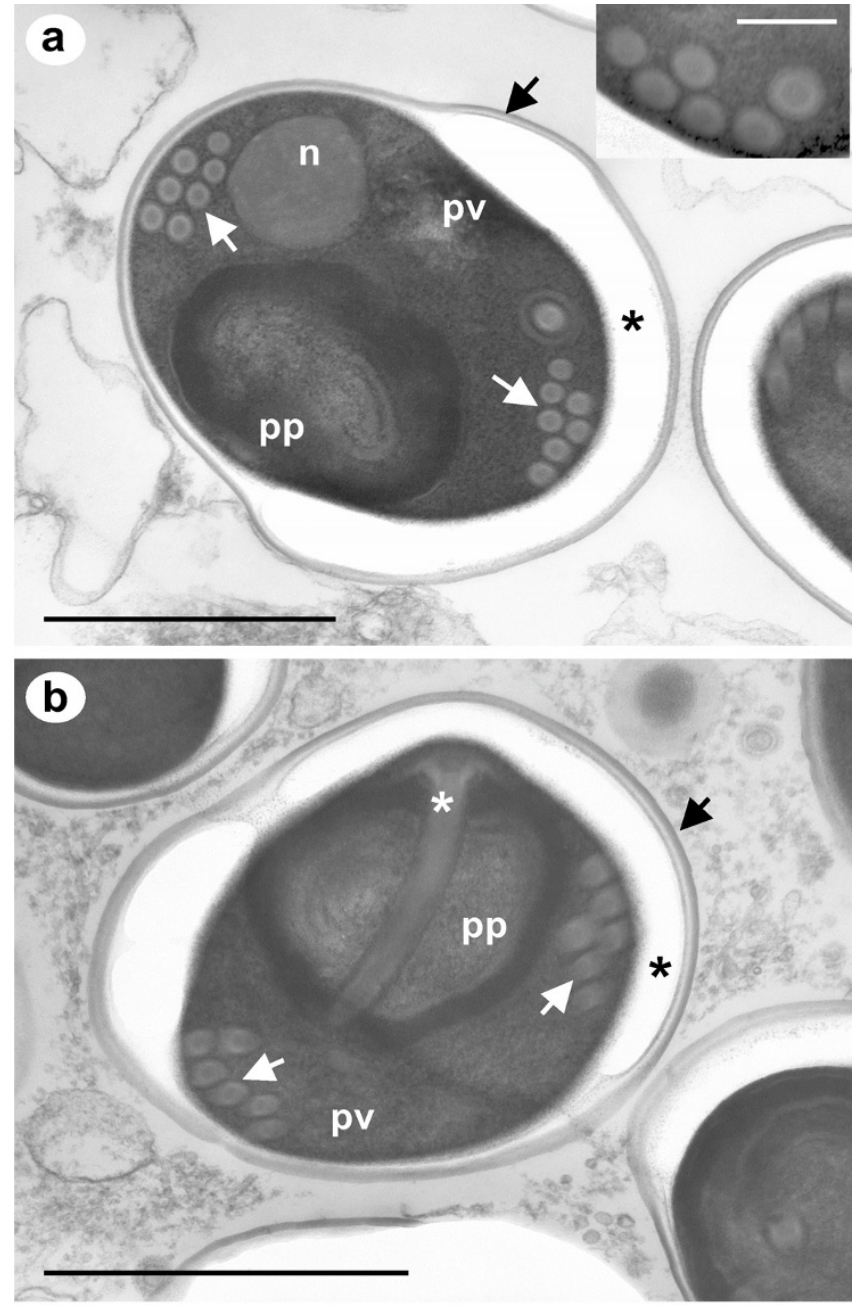

Figure I

a-b - TEM of mature spores of Desmozoon lepeophtherii n. gen., n. sp. Sagittal section of spores detailing seven coils of an isofilar polar filament (white arrows) in a double coil arrangement. The polar filament has an electron dense core and is composed of concentric layers of varying electron densities (inset a). A thick electron lucent endospore wall (black asterisks) is surrounded by a thinner electron dense exospore layer (black arrows). The single nucleus (n), posterior vacuole (pv) and polaroplast (pp) are all prominent features of the mature spore. The polaroplast is located at the anterior end of the spore and accommodates the manubroid part of the polar filament (white asterisk) and the attachment disc. Scale bars I $\mu \mathrm{m}(200 \mathrm{~nm}$ inset a).
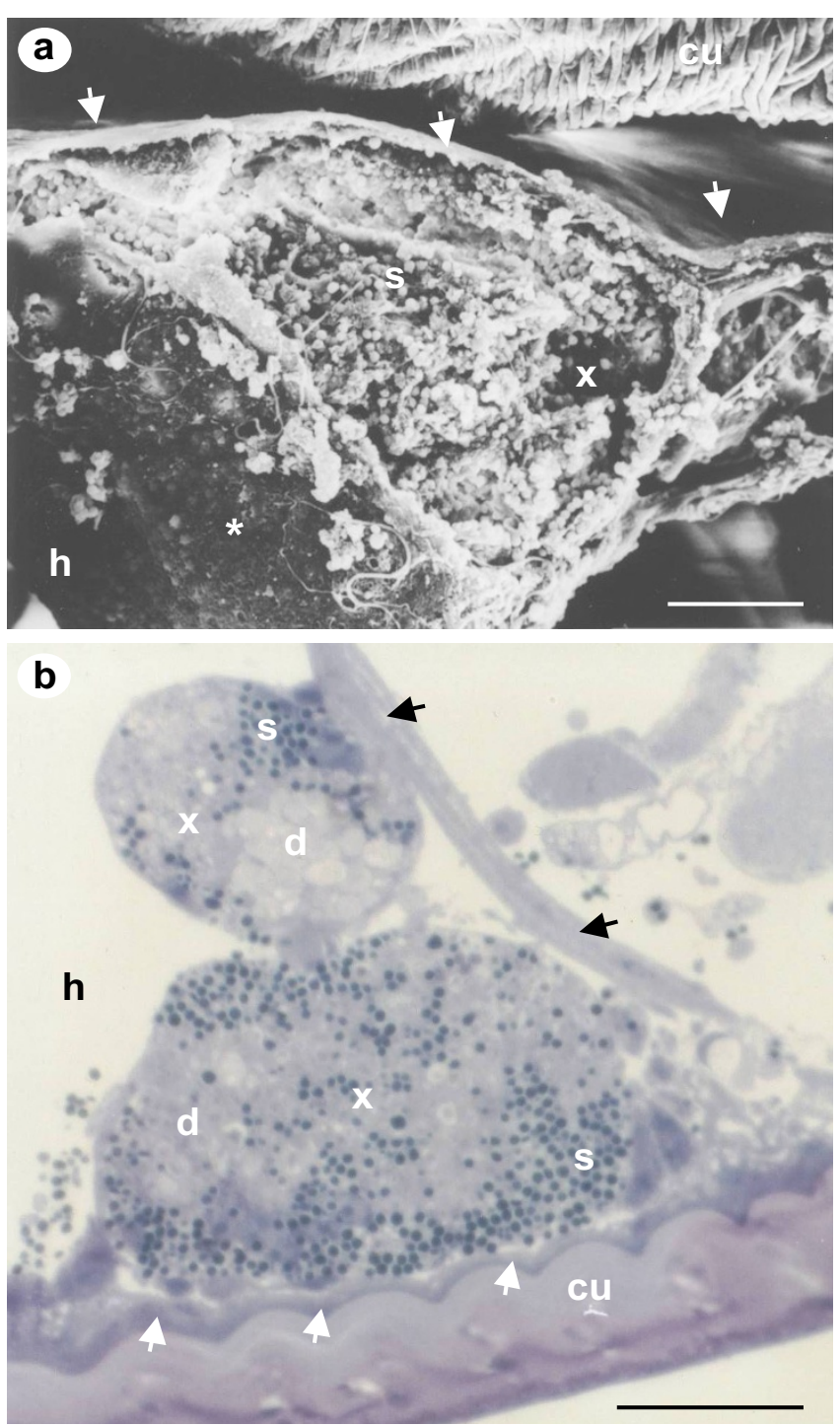

\section{Figure 2}

SEM of freeze-fractured $L$. salmonis and transverse abdominal semi-thin histological section. a) SEM of freeze-fractured louse showing a large xenoma $(x)$ developing beneath the cuticle (cu). The epidermal tissue layer remains uninfected directly beneath the cuticle (white arrows) but has a different more coarse appearance (white asterisk) bordering the haemocoel (h). The xenoma has been fractured open revealing that it is packed with microsporidian spores (s). b) Transverse abdominal semi-thin section from an infected louse. Developing xenomas $(x)$ contain both mature spores (s) and developing stages (d) and can originate from beneath the cuticle (cu) or from the haemocoelic divisions that separate the haemal sinuses (black arrows). The epidermal tissue layer beneath the cuticle remains intact (white arrows). Scale bars a $25 \mu \mathrm{m}$, b $50 \mu \mathrm{m}$. 


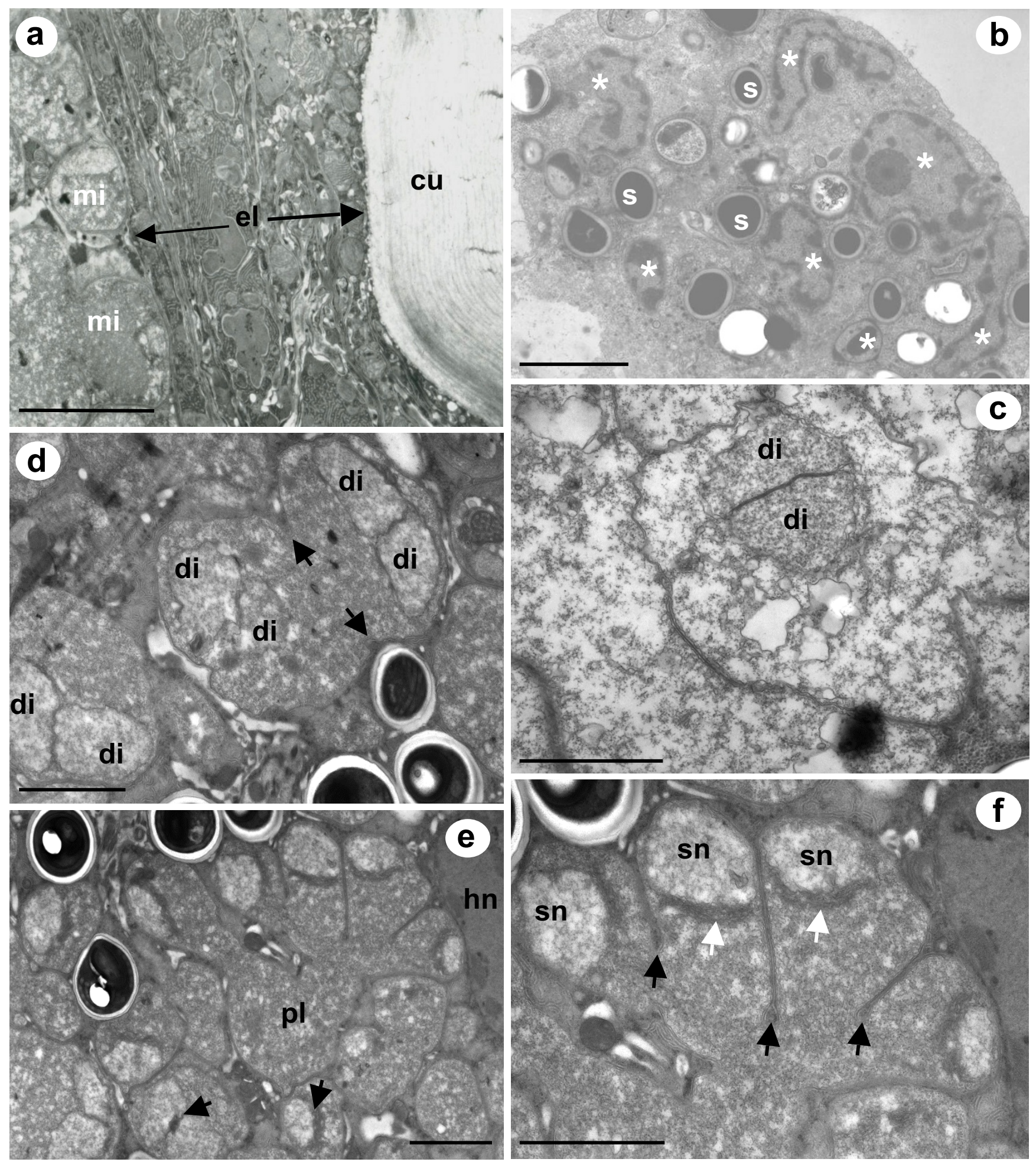

Figure 3 (see legend on next page) 
Figure 3 (see previous page)

TEM of microsporidian infection beneath the cuticle, xenoma structure and merogonial replication of Desmozoon lepeophtherii n. gen., n. sp. a) The microsporidian infection (mi) is found beneath the cuticle (cu) and originates from the innermost portion of the epidermal tissue layer (el). b) A small xenoma contains mature spores (s) and reveals that the host nucleus (white asterisks) is not infected by the microsporidian but is grossly hypertrophic and has numerous branches and folds. c) An early meront stage with a single nucleus in diplokaryotic formation (di). d) A divisional meront showing cytoplasmic constrictions (black arrows), that contains two nuclei in diplokaryotic arrangement (di). e) A large divisional merogonial plasmodium ( $\mathrm{pl}$ ) situated next to a host cell nucleus (hn), black arrows indicate nuclear activity associated with nuclear dissociation of the diplokaryon in neighbouring meronts. f) An enlarged view of the same plasmodium, with single unpaired nuclei (sn), undergoing division via plasmotomy (black arrows). White arrows indicate electron-dense laminate bodies lying on the nuclear membrane indicating recent nuclear activity due to nuclear dissociation of the diplokaryotic arrangement. Scale bars a-b $5 \mu \mathrm{m}$, c-f $2 \mu \mathrm{m}$.

nuclear fragments or multi-lobed nuclei (Fig. 3b); the microsporidian was never observed to have a close association with the host cell nucleus or seen as intranuclear at any stage of development. The microsporidian remained in direct contact with the host cell cytoplasm throughout the developmental cycle and did not form a complete interfacial envelope of either parasite-derived or hostderived origin that contained a typical number of spores.

Figure $3 c$ is an early meront and is the earliest microsporidian stage that was observed. The nucleus is in a diplokaryotic arrangement and the cytoplasm is electron lucent lacking other cellular organelles. The diplokaryotic nuclei of the early meronts divide to produce two diplokaryotic nuclei which locate at opposing cellular borders (Fig 3d). Cytokinesis follows this nuclear division and the cell divides by binary fission, producing two new meronts each with a diplokaryon (Fig 3d); during this division the cytoplasm has a much more granular appearance. The diplokaryotic nuclear arrangement was not observed after this point in the developmental phase and nuclear dissociation is assumed to have occurred. Nuclear dissociation is followed by multiple subsequent nuclear divisions, which are not directly linked to cytokinetic events, resulting in the formation of a large, paucinucleate, rounded, merogonial plasmodium, which ultimately divides by plasmotomy (Fig 3e). During division, the plasmodium contains very granular cytoplasm with no obvious organisation of organelles and the nuclei have electron-dense laminate bodies lying on the nuclear membrane, indicative of recent nuclear activity from either nuclear dissociation or recent division (Fig 3f).

The resulting uninuculeate stages represent the production of sporonts and the onset of sporogony. Sporonts have a higher degree of cellular organisation than meronts. Early sporonts have a precocious development of the polar filament which is associated with the nucleus and a complex of cytoplasmic cisternae that coalesce to form the polar filament bundles; there is a modest thickening of the plasmalemma prior to division (Fig 4a). Dur- ing sporogony the polar filament and its attachment apparatus, the anchoring disc, continue to develop and the plasma membrane continues to thicken (Fig 4b). The early formation of the anchoring disc is often seen to take place in association with a nuclear invagination (Fig 4b). During these preliminary stages of sporogony, numerous tubules are present in the host cell cytoplasm (Figs 4a-4c). The coils of the polar filament continue to mature with an electron dense core forming and membrane bound electron lucent inclusions appear in the posterior part of the spore between the developing bundles of polar filament (Fig 4c). These stages are considered to be sporoblasts that continue to develop into spores without further division. As the sporoblasts mature, the polar filament continues to become more electron-dense and show concentric patterns of electron density (inset Fig 4d). The ELIs become more prominent and are often associated with large electron dense particles located at the membrane (Fig 4d). Occasionally, sporoblast-like forms at a similar developmental stage retain two sets of polar filaments (Fig 4e). Immature spores start to reveal typical microsporidian spore-like features (Fig 4f). The exospore is fully formed before the endospore develops and the ELIs are now associated with the developing posterior vacuole. At this stage a fragile interfacial envelope can sometimes be seen surrounding the immature spore (Fig $4 \mathrm{f}$ ).

Membranous-like secretions were sometimes observed in the host cell cytoplasm during sporogony (Fig 5a-c). These secretions between $30-40 \mathrm{~nm}$ in thickness contained a central core of electron dense particles and appeared to develop at the external surface of maturing spores. The membranous-like secretions were occasionally seen free in the host cell cytoplasm as enclosed concentric membranous whorls (Fig 5c).

Host cell nuclei of microsporidian-infected cells were sometimes observed with intranuclear inclusions, which were of a crystalline appearance having a regular pattern (Figs 5d). 

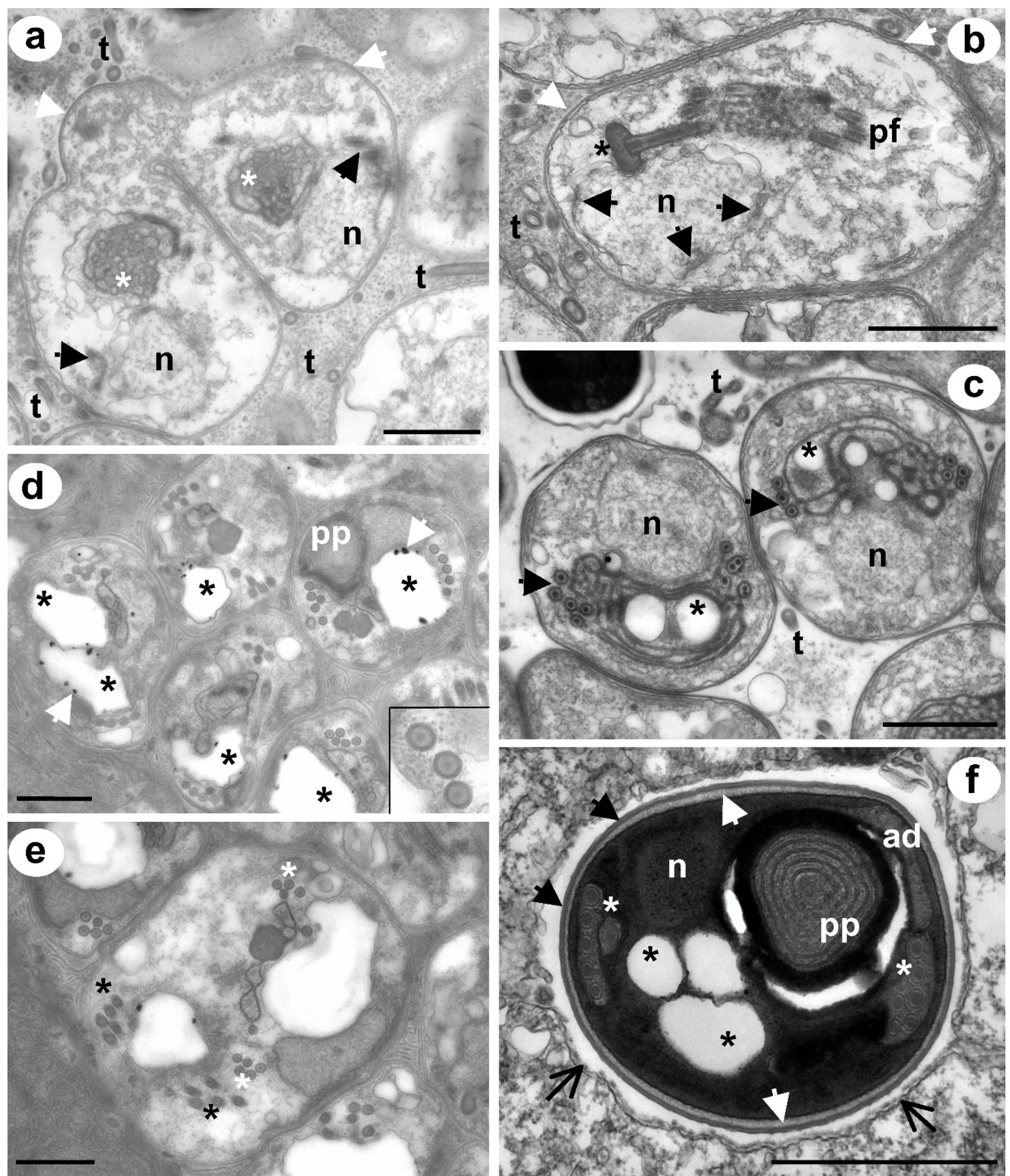

Figure 4 (see legend on next page) 
Figure 4 (see previous page)

TEM of sporogonial stages of Desmozoon lepeophtherii n. gen., n. sp. a) An early divisional sporont with tubules in the host cell cytoplasm has a modest thickening of the plasma membrane (white arrows) and precocious development of the pf (black arrows) associated with the nucleus and cytoplasmic cisternae (white asterisks) that start to form the pf bundles. b) Sporont with a thickening plasma membrane (white arrows), a diffuse nucleus showing signs of recent activity (black arrows), the developing ad (black asterisks) is associated with a nuclear invagination, from which the developing pf extends. Tubules are present in the host cell cytoplasm. c) Immature sporoblasts have a more defined nucleus and show signs of pf organisation in to bundles (black arrows), which are arranged in close proximity to large ELls (black asterisks), tubules are still present in the host cell cytoplasm. d) Maturing sporoblasts have features of mature spores such as a PP and a more mature pf. ELls (black asterisks) have dark granules associated with the membranes (white arrows). e) Some sporoblasts at an equivalent developmental stage to (d) have two sets of pf apparatus (white/black asterisks) both with associated ELls. f) An early spore with a fully formed exospore layer (black arrows) and a developing endospore layer (white arrows). This late stage shows a typical internal arrangement seen in mature spores; ad and pp are located at the anterior of the spore, the single nucleus and rows of pf (white asterisks) are medially positioned, ELls (black asterisks) are posteriorly located and will form part of the posterior vacuole. A secretion from the exospore forms a fragile interfacial envelope which creates a void surrounding the spore (open black arrows). All scale bars I $\mu \mathrm{m}$. ad (anchoring disc); n (nucleus); pf (polar filament); pP (polaroplast); t (tubules).

From the percentage divergence matrices (Table 1), D. lepeophtherii is most similar to members of the Nucleospora, ranging from 10.0-11.8\% divergence over approximately 850 bases of SSU sequence data; Enterocytozoon spp. are more distant at 18.3-20.2\% divergence. Percentage divergence within the Nucleospora was as high as $14.1 \%$ between species infecting non-salmonids (English sole and Atlantic halibut) and as low as $0.3 \%$ between salmonid species. Percentage divergence between the two species of Enterocytozoon ranged from 13.7-20.2\% depending on the genotype of E. bieneusi, and $1.5 \%$ between the two genotypes examined. Desmozoon lepeophtherii is most similar to the Nucleospora sp. infecting English sole with $10.0 \%$ divergence over 847 bases of the SSU examined

The phylogenetic tree (Fig 6) confirms that the results obtained with percentage divergence matrices were also observed using maximum parsimony analyses. Desmozoon lepeophtherii forms a well-supported clade with the Nucleospora sp. infecting English sole which forms as a sister group to the N. salmonis clade. The bootstrap support for these clades is $100 \%$. Enterocytozoon spp. are more basal in the tree and E. hepatopenaei does not group with the $E$. bieneusi genotypes, but forms a solitary branch between $E$. bieneusi and the Nucleospora clade containing Desmozoon. The outgroup Microsporidium sp. (DP), is a microsporidian that infects the intestinal wall of Daphnia, is related to other Daphnia-infecting species such as Microsporidium sp. clone B [7], and has been shown to be immediately basal to the family Enterocytozoonidae in independent phylogenetic analyses $[6,21]$.

\section{Discussion}

Tissue location of Desmozoon lepeophtherii in L. salmonis The epidermal layer in copepods is described as a flattened cellular layer containing a great number of membrane-bound vesicles and mitochondria, with a very complicated spatial arrangement [39]. This complex arrangement of cells was confirmed to be similar in L. salmonis in the present study (Fig 3a). The basal portion of the epidermal layer rests on a glycocalyx [39], which is also referred to as the basal lamina and functions as a basement membrane separating the epidermal layer from the underlying tissues and haemocoel [40]. The glycocalyx contains epidermal cells such as modified epithelial cells with tonofilaments, desmocytes or fibrocytes and tissue dwelling haemocytes [39]. Microsporidian xenomas develop from this location, but due to the extreme hypertrophy and transformation of infected host cells due to xenoma formation, their identity can only be hypothesised from our current knowledge. We believe that infection is primarily in the desmocytes, as infection is also seen along the haemocoelic divisions that have little or no such epidermal tissue layer. However, it is also possible that phagocytic haemocytes become infected, or are involved with the spread of the infection throughout the copepod, or are responsible for the initial transportation of spores from the portal of entry to the site of infection. Xenoma formation has not been reported for other members of the Enterocytozoonidae.

\section{Comparative ultrastructural features of Desmozoon and the Enterocytozoonidae (Table 2)}

The diplokaryotic arrangement of nuclei seen in early merogony in D. lepeophtherii is not seen in the other genera from the Enterocytozoonidae, although it was reported in the initial description of E. bieneusi by Desportes et al., [29]. This early diplokaryotic nuclear formation in E. bieneusi was later rejected by Cali and Owen [41] who suggested it was an artifact caused by the flattening of the nuclei by adjacent ELIs. An early plasmodial stage of Enterospora sp. has been observed with 'paired nuclei' [3] but the nuclear arrangement does not appear to be typical of a microsporidian diplokaryon. The lack of 

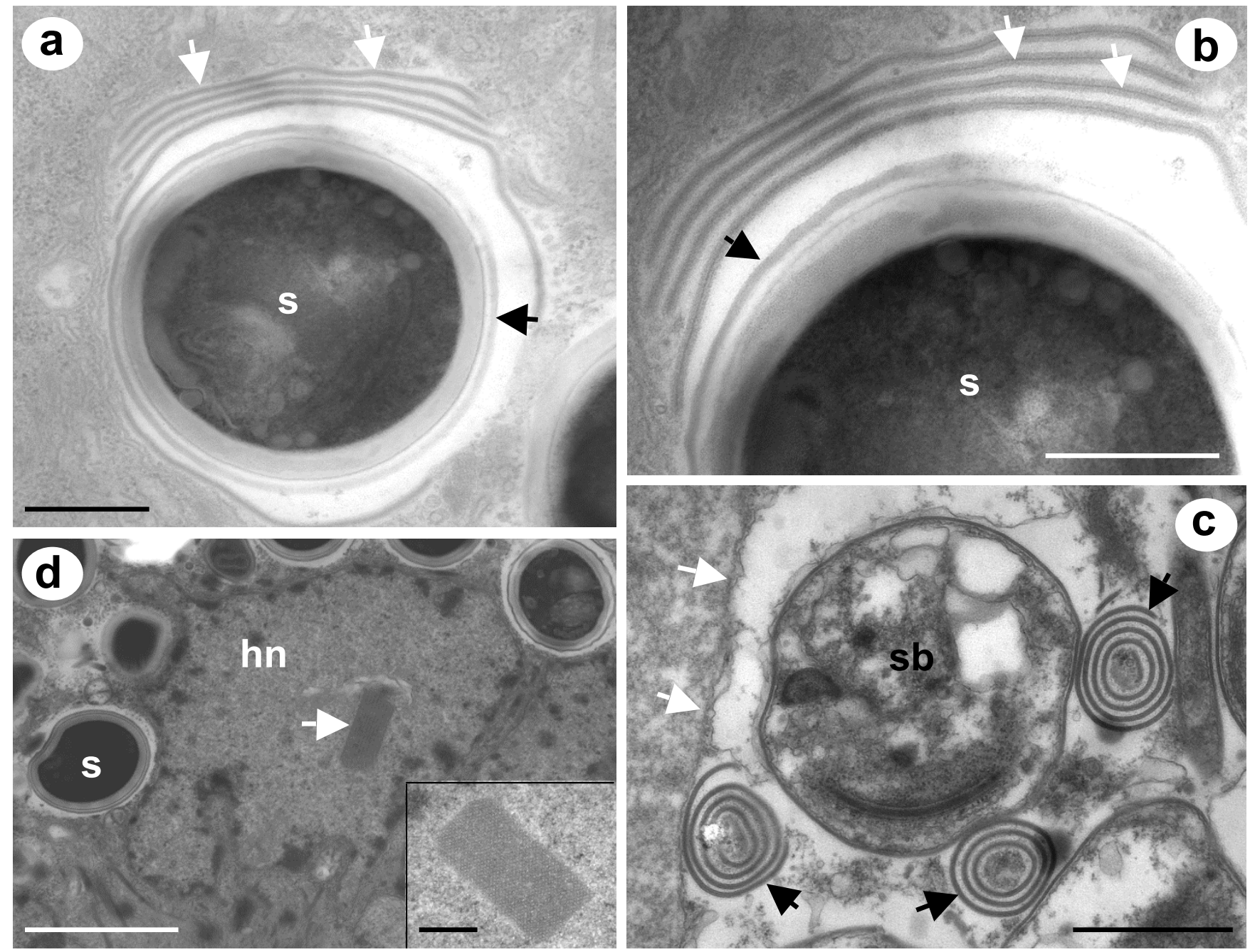

Figure 5

Other ultrastructural observations associated with Desmozoon lepeophtherii n. gen., n. sp. a and b) Secretions from mature spores (s) are sometimes observed that form multiple and regular layers which have a fine electron dense core, and surround the spore (white arrows). The secretions originate from the exospore surface and, when first produced, do not have an electron dense core (black arrows). c) At the border of a xenoma (white arrows) concentric whorls of the secretions have formed adjacent to a sporoblast (sb), the individual layers appear more compact but still maintain an electron dense core (black arrows). $d$ and inset) Host cell nuclei of microsporidian-infected cells were frequently observed with intranuclear inclusions, which were of a crystalline appearance with a regular pattern. Scale bars a, b and d (inset) $500 \mathrm{~nm}, \mathrm{c} \mathrm{I} \mu \mathrm{m}, \mathrm{d} 2 \mu \mathrm{m}$.

complete descriptions of early merogonial stages for some members of the Enterocytozoonidae means that a brief or early diplokaryotic stage in the merogonial development cycle should not be completely ruled out for other members of the family.

All members of the Enterocytozoonidae share certain developmental features. Whilst early merogonial stages have not always been well characterized and remain somewhat contentious, all currently described species develop large sporogonial syncitia in which the polar filament extrusion apparatus forms and develops prior to eventual division to sporoblasts. This precocious development of the polar filament, prior to final division and its association with ELIs in large sporogonial plasmodia, are features that are unique to this family of microsporidia. In the three genera of the family: Enterocytozoon, Nucleospora and Enterospora, the sporogonial plasmodium develops directly from the merogonial plasmodium without division and continues to mature to form the characteristic sporogonial syncitium. This direct transformation is assumed to occur as no division of the multinucleated merogonial stages have been reported for these taxa, only 
Table I: Percentage divergence of SSU rDNA sequences for members of the Enterocytozoonidae and related taxa.

\begin{tabular}{llllllllllll}
\hline & I. & 2. & 3. & 4. & 5. & 6. & 7. & 8. & 9. & I0. & II. \\
\hline I. Desmozoon lepeophtherii & & 0.202 & 0.183 & 0.188 & 0.118 & 0.112 & 0.100 & 0.114 & 0.116 & 0.251 & 0.256 \\
\hline 2. Enterocytozoon bieneusi (human) & 827 & & 0.015 & 0.202 & 0.167 & 0.169 & 0.195 & 0.174 & 0.184 & 0.223 & 0.261 \\
\hline 3. Enterocytozoon bieneusi (bird) & 458 & 845 & & 0.137 & 0.147 & 0.147 & 0.179 & 0.151 & 0.143 & 0.203 & 0.239 \\
\hline 4. Enterocytozoon hepatopenaei & 690 & 819 & 607 & & 0.171 & 0.171 & 0.203 & 0.174 & 0.164 & 0.233 & 0.264 \\
\hline 5. Nucleospora salmonis (CS) & 851 & 1247 & 855 & 836 & & 0.001 & 0.121 & 0.003 & 0.005 & 0.212 & 0.249 \\
\hline 6. Nucleospora salmonis (RT) & 845 & 1228 & 855 & 836 & 1250 & & 0.120 & 0.003 & 0.005 & 0.214 & 0.249 \\
\hline 7. Nucleospora sp. (ES) & 847 & 1228 & 853 & 839 & 1247 & 1246 & & 0.123 & 0.141 & 0.226 & 0.254 \\
\hline 8. Nucleospora salmonis (AS) & 814 & 1199 & 854 & 835 & 1220 & 1219 & 1216 & & 0.009 & 0.221 & 0.253 \\
\hline 9. Nucleospora salmonis (AH) & 671 & 756 & 561 & 774 & 776 & 776 & 775 & 775 & & 0.247 & 0.256 \\
\hline I0. Microsporidium sp. (DP) & 872 & 1246 & 854 & 834 & 1270 & 1245 & 1244 & 1215 & 772
\end{tabular}

Distances (percentage divergence/100) above the diagonal and number of bases of SSU rDNA analysed below the diagonal

$\mathrm{AH}=$ Atlantic halibut; $\mathrm{AS}=$ Atlantic salmon; $\mathrm{CS}=$ chinook salmon; $\mathrm{DP}=$ Daphnia; $\mathrm{ES}=$ English sole; $\mathrm{RT}=$ rainbow trout

their development and subsequent maturation to sporogonial forms.

Syncitial masses, such as merogonial and sporogonial plasmodia, are large proliferative stages that can occupy a significant proportion of the microsporidian-infected cell, which would make it unlikely for them to be missed during TEM examination of ultrathin sections of infected material. Therefore, it must be concluded that $D$. lepeophtherii develops without the formation of the sporogonial plasmodium that is typical for the family Enterocytozoonidae. Instead, the merogonial plasmodium divides to form uninucleate sporonts, which undergo a number of nuclear divisions, all of which are followed by cellular division, resulting in a final division to form two sporoblasts. The lack of the formation of the characteristic sporogonial plasmodium in Desmozoon might be considered sufficiently different for it not to be included in the Enterocytozoonidae. However, a precocious development of the polar filament can be found in young divisional sporonts (Fig 4a) and two sets of fully formed extrusion apparatus are sometimes found in large sporoblasts that are presumably yet to divide (Fig 4e). ELIs are also present throughout much of the developmental cycle in Desmozoon, being at their largest during late sporont and early sporoblast formation and reduced or absent in mature spores. Cali and Owen [41] suggested that the ELIs observed in E. bieneusi were storage vacuoles and probably involved in the formation of the polar filament and other spore structures. The ELIs in Desmozoon develop in close association with cytoplasmic cisternae and the developing polar filament (Fig 4c) supporting this hypothesis. They are also associated with the formation of the posterior vacuole, as they are positioned posteriorly in the developing spore ultimately where the posterior vacuole develops (Fig 4f). The presence of ELIs in Desmozoon during sporogony and the early development of the polar filament seen as early as young divisional sporonts are typical features of the Enterocytozoonidae that are seen in all the described species of the family and suggest that this microsporidian should be placed in the Enterocytozoonidae in spite of the lack of a sporogonial plasmodium.

Although some characteristics are present in all family members, there can be notable differences in the cellular processes involved in their formation. Morphogenesis of the polar filaments proceeds differently in the three described genera of the Enterocytozoonidae. In E. bieneusi a large electron dense body associated with vesiculotubular networks form electron dense disc-like structures (EDDs), which appear throughout the plasmodium and then fuse into arcs forming the polar filament coils [33,41]. In Nucleospora spp. the polar filament does not coalesce from EDDs but from cylinders or tubular structures that are associated with ribosome rich cytoplasm delimited by the ER cisternae [32,33]. In Enterospora, mul- 


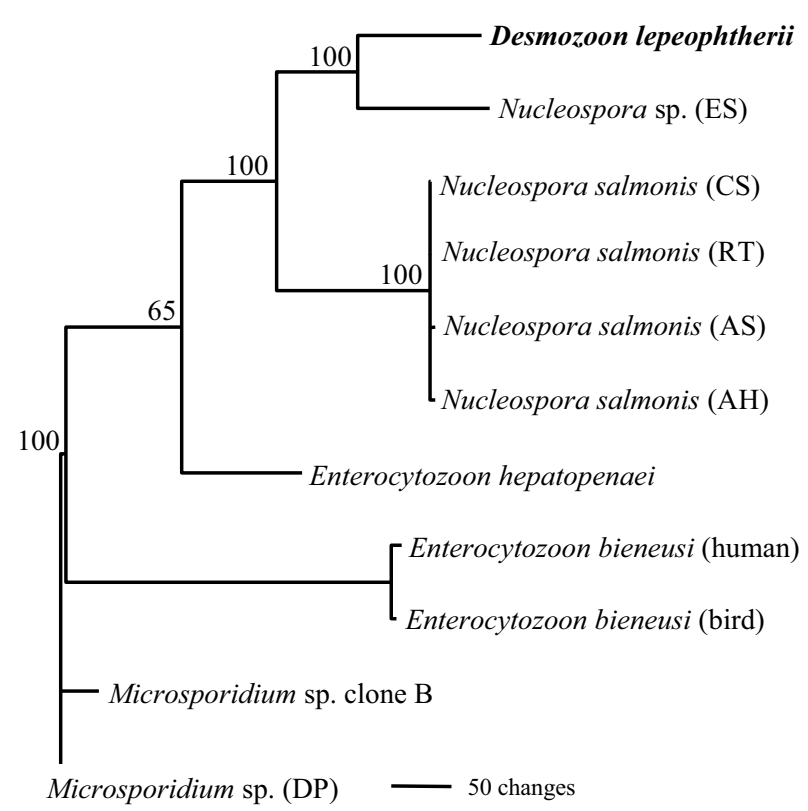

Figure 6

Maximum parsimony generated phylogenetic tree constructed using SSU rDNA sequence alignments from representative taxa of the Enterocytozoonidae. The tree utilises 328 parsimony informative characters and is rooted to the related Microsporidium sp. infecting Daphnia. The scale represents number of base changes and the numbers at the nodes indicate bootstrap support values from 1000 resamplings. $\mathrm{AH}=$ Atlantic halibut; $\mathrm{AS}=$ Atlantic salmon; CS = chinook salmon; DP = Daphnia; $E S=$ English sole; $\mathrm{RT}=$ rainbow trout.

tiple spherical membrane-bound vesicles are present throughout the cytoplasm of the plasmodium [4], which presumably correspond to polar filament precursors and are similar to those seen in E. bieneusi although not as electron dense. The development of the polar filament in D. lepeophtherii is more similar to that of Nucleospora spp. as no typical EDDs develop and the polar filament develops within the cytoplasmic cisternae of ER (Fig 4a). However, the early assembly of the polar filament does not take place in the plasmodium as the merogonial plasmodium divides to form sporonts before being transformed to a sporogonial syncitium in this species.

Mature spores of $D$. lepeophtherii share many characteristics with those in the Enterocytozoonidae (Table 2). All members of the family have small round to ovoid (subspherical) spores, a single nucleus and between 4-8 turns of an isofilar polar filament, usually in a double coil, are polysporous and lack a complete interfacial envelope at all developmental stages.

\section{Molecular phylogenetics of the Enterocytozoonidae}

Desmozoon lepeophtherii has been shown to be robustly supported as a member of the Enterocytozoonidae using phylogenetic analyses [[21], present study]. The Enterocytozoonidae form a small monophyletic group that is part of a larger clade described as being terrestrial in origin, but having evolved from ancestral freshwater microsporidians [42].

The Enterocytozoonidae has recently increased its size with respect to the number of genera and described species it contains. However, all the new descriptions are from aquatic marine crustacean hosts $[3,4,14]$, including that in the present study. Unfortunately there are no DNA sequences available for the genus Enterospora infecting marine crabs, but ultrastructural descriptions adequately placed them in the Enterocytozoonidae. The increasing occurrence of microsporidia infecting crustacea in the Enterocytozoonidae is not unexpected, as a related gutinfecting microsporidian from Daphnia has been shown to be consistently placed as basal to the group $[6,21]$. Unfortunately no ultrastructural data is available for this parasite, but a similar microsporidian has been recently further documented from Daphnia populations in European lakes [7]. As more species are described and more gene sequences become available for the Enterocytozoonidae, some of these unresolved phylogenetic issues will hopefully be clarified. But, current phylogenetic analyses suggest that the Enterocytozoonidae is likely to have evolved from a common ancestor infecting a crustacean host. The phylogenetic importance of crustacean-infecting microsporidia in understanding the origins of species like Enterocytozoon bieneusi that infect humans may be significant.

\section{Other ultrastructural features of Desmozoon lepeophtherii in Lepeophtheirus salmonis}

Numerous appendages/tubules were observed in the host cell cytoplasm during sporogony (Fig 4a-c). Takvorian and Cali [43] reviewed the form and function of microsporidian appendages, suggesting four different types. The appendages observed in this study most closely resemble the type I tubules described from Glugea stephani (Hagenmüller, 1899), but, during the present study, evidence that the tubules were continuous with the parasite plasmalemma was not apparent. The function of these appendages remains unknown but they have been suggested to facilitate host-parasite interchange of materials [43]. Microsporidian tubules have not been reported in the Enterocytozoonidae previously. They are rare amongst microsporidia that develop in direct contact with the host cell cytoplasm, but developing stages of both E. bieneusi and $E$. hepatopenaei have been observed with numerous tubule-like cytoplasmic projections extending into the host cell cytoplasm $[14,33]$. The lack of distinct cytoplas- 
Table 2: Characteristics of the four microsporidian genera contained within the family Enterocytozoonidae

\begin{tabular}{|c|c|c|c|c|}
\hline Feature & Desmozoon n. gen. & Enterocytozoon & Nucleospora & Enterospora \\
\hline Host & $\begin{array}{l}\text { Caligid copepod, } \\
\text { Lepeophtheirus salmonis }\end{array}$ & $\begin{array}{l}\text { Mammals and birds a and } \\
\text { penaeid shrimp }\end{array}$ & $\begin{array}{l}\text { Fish } \\
\text { (salmonid, freshwater, and } \\
\text { marine) }\end{array}$ & Marine decapod crabs \\
\hline Host cell-type infected & $\begin{array}{l}\text { Desmocytes in the } \\
\text { glycocalyx bordering } \\
\text { haemocoelic cavities }\end{array}$ & $\begin{array}{l}\text { Enterocytes a } \\
\text { Tubule epithelial cells of } \\
\text { the hepatopancreas }{ }^{b}\end{array}$ & $\begin{array}{l}\text { Haemopoietic cells and } \\
\text { blood leukocytes }{ }^{c} \\
\text { Intestinal epithelial cells }{ }^{d}\end{array}$ & $\begin{array}{l}\text { Hepatopancreas epithelial } \\
\text { cells }\end{array}$ \\
\hline $\begin{array}{l}\text { Mature spore shape and } \\
\text { size }\end{array}$ & $\begin{array}{l}\text { Round to sub-spherical } \\
2.34 \times 1.83( \pm 0.01) \text { fresh }\end{array}$ & $\begin{array}{l}\text { Spherical to ovoid, } 1.5 \times \\
0.8 \text { a }(\text { fixed) } \\
\text { Oval I.I } \times 0.7 \\
\text { (fresh/percoll-purified) }\end{array}$ & $\begin{array}{l}\text { ovoid to pyriform, } 2 \times 1 \\
\left(\text { fixed) }{ }^{c}\right. \\
\text { ellipsoidal } 1.6 \times 0.8 \\
\text { (ultrathin sections) }^{d}\end{array}$ & $\begin{array}{l}\mathrm{I} .3( \pm 0.02) \times 0.7( \pm 0.01) \\
\text { (fixed) }\end{array}$ \\
\hline $\begin{array}{l}\text { Number of turns and type } \\
\text { of polar filament }\end{array}$ & $\begin{array}{l}\text { Isofilar, 5-8 turns } \\
\text { (usually a double layer) }\end{array}$ & $\begin{array}{l}\text { 4-7 turns (double layer) } \\
5-6 \text { turns (double layer) }\end{array}$ & $\begin{array}{l}\text { 8-12 turns (single or } \\
\text { double layer)c } \\
4-5 \text { turns (double layer) d }\end{array}$ & 4-5 turns (double layer) \\
\hline Spore production & $\begin{array}{l}\text { Polysporous, without } \\
\text { interfacial envelop }\end{array}$ & $\begin{array}{l}\text { Polysporous, without } \\
\text { interfacial envelop }\end{array}$ & $\begin{array}{l}\text { Polysporous, without } \\
\text { interfacial envelop }\end{array}$ & $\begin{array}{l}\text { Polysporous, without } \\
\text { interfacial envelop }\end{array}$ \\
\hline Location in host cell & Cytoplasm & Cytoplasm & Nucleoplasm (intranuclear) & Nucleoplasm (intranuclear) \\
\hline Earliest stage observed & Diplokaryotic meront & Uninucleate meront & Uninucleate meront & Binucleate meront \\
\hline $\begin{array}{l}\text { Plasmodium/syncitium } \\
\text { stage }\end{array}$ & $\begin{array}{l}\text { Merogonial plasmodium } \\
\text { divides via plasmotomy. } \\
\text { No sporogonial } \\
\text { plasmodium present. }\end{array}$ & $\begin{array}{l}\text { Merogonial plasmodium } \\
\text { transforms to sporogonial } \\
\text { plasmodium without prior } \\
\text { division. }\end{array}$ & $\begin{array}{l}\text { Merogonial plasmodium } \\
\text { transforms to sporogonial } \\
\text { plasmodium without prior } \\
\text { division. }\end{array}$ & $\begin{array}{l}\text { Merogonial plasmodium } \\
\text { transforms to sporogonial } \\
\text { plasmodium without prior } \\
\text { division. }\end{array}$ \\
\hline Key references & Present study, $[21,23]$ & $\begin{array}{l}\text { a }[29,31,33,4 \mid] \\
\mathrm{b}[14]\end{array}$ & $\begin{array}{l}c[32,33] \\
d[34]\end{array}$ & {$[3,4]$} \\
\hline
\end{tabular}

mic tubules in other members of the Enterocytozoonidae may be due to the common features of their sporogony resulting in the presence of sporogonial syncitia in all cases. The microsporidian tubules in D. lepeophtherii are only associated with sporogony and are more prominent during early sporogony, particularly in divisional young sporonts which are absent in other members of the family. Furthermore, microsporidian tubules have never been reported for intranuclear microsporidians. Tubule formation is not typically associated with xenoma-forming microsporidia and is more often observed in species that develop complete interfacial envelopes [44].

The microsporidian infection in L. salmonis does indeed complete its developmental cycle lacking any type of complete interfacial envelope. However, during late sporogony there were membranous secretions regularly observed near the outer surface of sporoblasts, occasionally in multiple layers (Fig 5a-b). These are thought to be parasitederived secretions as no host cell remnants were associated with them. These membranous secretions were never seen to completely isolate the sporoblast from the host cell cytoplasm and hence cannot be considered an interfacial envelope. The structures were also observed as continuous concentric circular membranous whorls, whose function was not apparent (Fig 5c). These membranous secretions are possibly partially formed parasite derived interfacial envelopes or associated with or derived from the cytoplasmic tubules present during early sporogony.
Similar non-persistent parasite derived interfacial envelopes have been reported from Vairimorpha necatrix (Kramer, 1965) where envelopes are formed during sporogony, which only sometimes develop to fully enclose the sporoblasts [44]. Similar membranous structures, described as type IV cytoplasmic tubules, have also been observed in sporophorous vesicles during sporogony in $V$. necatrix $[44,45]$.

The intranuclear inclusions observed in infected host cells had an appearance consistent with either crystalline inclusions or viral like particles VLPs [46] (Fig 5d). Microsporidian infections have previously been associated with simultaneous viral infections. Both Nucleospora and Enterocytozoon have been reported to be associated with retroviral infection of their hosts. Nucleospora salmonis has been found in fish infected with the retrovirus that is believed to be the cause of plasmacytoid leukaemia $[47,48]$, and $E$. bieneusi is found predominately in HIV-infected patients, although this is largely accepted as opportunistic infections due to a lowering of the immune status caused by the viral infection [49]. Intranuclear and intracytoplasmic crystalline inclusions are frequently associated with other cell abnormalities such as tumour cells and leukaemic conditions; intranuclear crystalline and paracrystalline inclusions have also been regularly associated with virally infected cells [46]. The VLPs seen in the present study are not thought to be related to the microsporidian infection but could warrant further study. 


\section{Taxonomic summary}

Phylum: Microsporidia (Balbiani, 1882)

Class: Microsporea (Levine \& Corliss, 1963)

Order: Microsporida (Balbiani, 1882)

Family: Enterocytozoonidae (Cali \& Owen, 1990)

\section{Specific diagnosis}

Spores are round to sub-spherical, with an isofilar polar filament with 5-8 turns in a double layer. Entire development is in direct contact with the host cell cytoplasm. Large xenomas develop from the glycocalyx border that is immediately basal to the epidermal tissue layer beneath the cuticle, and desmocytes are thought to be the most likely host cell infected. Early diplokaryotic meronts develop into large plasmodia, with unpaired nuclei that divide by plasmotomy to form sporonts. During sporogony there is a precocious development of the polar filament extrusion apparatus which is associated with electron lucent inclusions. The polar filament can be fully arranged and well developed prior to the final division to form two sporoblasts. SSU rDNA sequence data is most similar to members of the Nucleospora and its position is robustly supported within the Enterocytozoonidae.

Type host: Lepeophtheirus salmonis (Krøyer) ex Salmo salar L.

Location: Numerous Atlantic salmon farms on the west coast of Scotland.

Type location: Toward Point, Argyll. Grid reference NS $137672 \mathrm{~GB}\left(55^{\circ} 51^{\prime} \mathrm{N}, 4^{\circ} 58^{\prime} \mathrm{W}\right)$.

Site of infection: Desmocytes associated with the glycocalyx border, basal to the epidermal tissue layer under the cuticle and along haemocoelic divisions.

Etymology: The genus name Desmozoon refers to the cell type infected. Desomcyte: any elongated interstitial cell, as in fibrocyte or fibroblast. The specific name lepeophtherii refers to the generic name of the parasitic copepod host (Lepeophtheirus).

Type material: Two hapantotype ultrathin TEM sections have been submitted to the collections of the Natural History Museum, London, and assigned the accession numbers 2009: 11: 18:1 and 2009: 11: 18: 2

\section{Conclusion}

The presence of a diplokaryotic stage during early merogony that undergoes nuclear dissociation and develops to form a merogonial plasmodium that divides to yield uni- nucleate sporonts has not been observed in the Enterocytozoonidae before. However, the typical family traits of the precocious development of the polar filament and the presence of ELIs were consistently observed, albeit in sporonts instead of a sporogonial plasmodium. Phylogenetic analyses consistently and robustly place Desmozoon lepeophtherii with other members of the Enterocytozoonidae as a monophyletic group, supporting the ultrastructural findings. This study highlights the importance of supplying a SSU rDNA sequence when describing new species of microsporidia. It is increasingly apparent that certain ultrastructural features, such as the diplokaryotic arrangement of nuclei can be lost or gained very rapidly over evolutionary time [42] and, following such characters leads to unacceptable polyphyletic groupings defined by character states that have evolved separately on numerous occasions and are not derived from a common ancestor [42]. Therefore the use of gene sequences to infer phylogenetic relatedness is extremely valuable and is vital for resolving the higher taxonomic issues in the microsporidia.

These results of this study lead us to the conclusion that the microsporidian hyperparasite of L. salmonis should be included in the Enterocytozoonidae. But, due to the unique ultrastructural features observed, xenoma formation, the novelty of the parasitic copepod host and the $10 \%$ sequence divergence seen in the SSU rDNA to its closest relative, that a new genus should be erected; the name Desmozoon lepeophtherii n. gen. n. sp. is proposed.

\section{List of abbreviations}

TEM: transmission electron microscopy; SEM: scanning electron microscopy; SSU rDNA: small subunit ribosomal DNA; SSU: small subunit; ELIs: electron lucent inclusions; EDD: electron dense disc-like structures; ER: endoplasmic reticulum; VLPs: virus-like particles.

\section{Competing interests}

The authors declare that they have no competing interests.

\section{Authors' contributions}

MF collected material and prepared and performed the TEM and DNA analyses. MF and CS analysed the data and prepared the manuscript.

\section{References}

I. Sprague V, Couch J: An annotated list of protozoan parasites, hyperparasites and commensals of decapod crustacea. J Protozool 197I, 18:526-537.

2. Olson RE, Tiekotter KL, Reno PW: Nadelspora canceri n.g., n.s. an unusual microsporidian parasite of the Dungeness crab, Cancer magister. J Euk Microbiol 1994, 4 I :349-359.

3. Stentiford GD, Bateman KS: Enterospora sp., an intranuclear microsporidian infection of hermit crab Eupagurus bernhardus. Dis Aquat Org 2007, 75:61-72.

4. Stentiford GD, Bateman KS, Longshaw M, Feist SW: Enterospora canceri n. gen., n. sp., intranuclear within the hepatopancreas 
of the European edible crab Cancer pagurus. Dis Aquat Org 2007, 75:6I-72.

5. Martinez MA, Vivares CP, Rocha RD, Fonseca AC, Andral B, Bouix G Microsporidiosis on Artemia (Crustacea, Anostraca) Light and electron microscopy of Vavraia anostraca sp. nov. (Microsporidia: Pleistophoridae) in the Brazilian Solar Salterns. Aquaculture 1992, 107:229-237.

6. Refardt D, Canning EU, Mathis A, Cheney SA, Lafranchi-Tristem NJ, Ebert D: Small subunit ribosomal DNA phylogeny of microsporidia that infect Daphnia (Crustacea: Cladocera). Parasitology 2002, I 24:38I-389.

7. Wolinska J, Giessler S, Koerner H: Molecular identification and hidden diversity of novel Daphnia parasites from European lakes. App Environ Microbiol in press.

8. Diarra K, Toguebaye BS: Ultrastructure of Nosema stenocypris (Diarra \& Toguebaye), 1994, a microsporidian parasite of Stenocypris major (Crustacea, Ostracoda, Cyprididae). Archiv Fur Protisten 1996, 146:363-367.

9. Lightner DV: A handbook of shrimp pathology and diagnostic procedures for disease control of cultured penaeid shrimp Baton Rouge: World Aquaculture Society; 1996.

10. Azevedo C, Corral L, Vivares CP: Ultrastructure of the microsporidian Inodosporus octospora (Thelohaniidae), a parasite of the shrimp Palaemon serratus (Crustacea, Decapoda). Dis Aquat Org 2000, 41:15I-158.

II. Azevedo C: Ultrastructural aspects of a new species, Vavraia mediterranica (Microsporidia, Pleistophoridae), parasite of the French Mediterranean shrimp, Crangon crangon (Crustacea, Decapoda). J Invert Path 200I, 78:194-200.

12. Clotilde-Ba FL, Toguebaye BS: Infection of Penaeus monodon (Fabricius, 1798) (Crustacea, Decapoda, Penaeidae) by Agmasoma penaei (Microspora, Thelohaniidae) in Senegal, West Africa. Bull Eur Ass Fish Pathol 2001, 21:157-159.

13. Toubiana M, Guelorget O, Bouchereau JL, Lucien-Brun H, Marques A: Microsporidians in penaeid shrimp along the west coast of Madagascar. Dis Aquat Org 2004, 58:79-82.

14. Tourtip S, Wongtripop S, Stentiford GD, Bateman KS, Sriurairatana S, Chavadej J, Sritunyalucksana K, Withyachumnarnkul B: Enterocytozoon hepatopenaei sp. nov. (Microsporida: Enterocytozoonidae), a parasite of the black tiger shrimp Penaeus monodon (Decapoda: Penaeidae): fine structure and phylogenetic relationships. J Invert Path 2009, 102:21-29.

15. Dunn AM, Terry RS, Smith JE: Transovarial transmission in the microsporidia. Adv Parasitol 2001, 48:57-100.

16. Freeman MA, Turnbull JF, Yeomans WE, Bean CW: Prospects for management strategies of invasive crayfish populations with an emphasis on biological control. Aquat Conserv, Aug 2009 in press.

17. Kiryu Y, Behringer DC, Landsberg JH, Petty BD: Microsporidiosis in the Caribbean spiny lobster Panulirus argus from southeast Florida, USA. Dis Aquat Org 2009, 83:237-242.

18. Sprague V, Vavra J: Systematics of the microsporidia. In Comparative Pathobiology Volume 2. Edited by: Bulla LA, Cheng CC. New York: Plenum Press; 1977: I-5 I0.

19. Voronin VN: Ultrastructure and horizontal transmission of Gurleya macrocyclopis (Protozoa, Microspora) to Macrocylops albidus (Crustacea, Copepoda). J Invert Path 1996, 67: 105-107.

20. Bronnvall AM, Larsson JIR: Ultrastructure and light microscopic cytology of Agglomerata lacrima n. sp. (Microspora, Duboscqiidae) a microsporidian parasite of Acanthocyclops vernalis (Copepoda, Cyclopidae). Eur J Protistol 200I, 37:89-I0I.

21. Freeman MA, Bell AS, Sommerville C: A hyperparasitic microsporidian infecting the salmon louse, Lepeophtheirus salmonis : an rDNA-based molecular phylogenetic study. J Fish Dis 2003, 26:667-676.

22. Vavra J, Hyliš M, Obornik M, Vossbrink CR: Microsporidia in aquatic microcrustacea: the copepod Microsporidium Marssoniella elegans Lemmermann, 1990 revisited. Folia Parasitol 2005, 52:163-172.

23. Freeman MA: Potential biological control agents for the salmon louse Lepeophtheirus salmois (Krøyer 1837). PhD thesis 2002 [http://hdl.handle.net//893//685]. University of Stirling, Institute of Aquaculture http://libcat.stir.ac.uk/record=b| 313993 S5

24. Durfort M, Vallmitjana L: Ultraestructura de meronts y esporas de Unikaryon mytilicolae (Durfort, Vallmitjana y Vivares,
1980), (Microspora, Unikaryionidae) hiperparasito del copepodo Mytilicola intestinalis, Steuer. Rev lbér Parasitol 1982, 42: $143-160$

25. Coste F, Bouix G: Two hyperparasitic microsporidia of both trematodes and copepods of teleost fishes [abstract No 107]. 36th Annual meeting of the Groupment des Protistologues de Langue Française (GPLF). J Euk Microbiol 1999, 46: I4a.

26. Andreadis TG: Experimental transmission of a microsporidian pathogen from mosquitoes to an alternate copepod host. Proc Nat Acad Sci USA 1985, 82:5574-5577.

27. Andreadis TG: Ultrastructural characterisation of meiospores of six new species of Amblyospora (Microsporidia: Amblyosporidae) from northern Aedes (Diptera: Culicidae) mosquitoes. J Euk Microbiol 1994, 4 I: I 47- I54.

28. Vossbrinck CR, Andreadis TG, Vavra J, Becnel J]: Molecular phylogeny and evolution of mosquito parasitic microsporidia (Microsporidia: Amblyosporidae). J Euk Microbiol 2004, 5 I:88-95.

29. Desportes I, Lecharpentier Y, Galian A, Bernard F, Cochandpriollet B, Lavergne A, Ravisse P, Modigliani R: Occurrence of a new microsporidan Enterocytozoon bieneusi n. g. n. sp., in the enterocytes of a human patient with AIDS. J Protozool 1985, 32:250-254.

30. Dengjel B, Zahler M, Hermanns W, Heinritzi K, Spillmann T, Thomschke A, Loscher T, Gothe R, Rinder H: Zoonotic potential of Enterocytozoon bieneusi. J Clin Microbiol 200I, 39:4495-4499.

31. Santín M, Fayer R: Enterocytozoon bieneusi genotype nomenclature based on the internal transcribed spacer sequence: a consensus. J Euk Microbiol 2009, 56:34-38.

32. Chilmonczyk S, Cox WT, Hedrick RP: Enterocytozoon salmonis $\mathbf{n}$. sp. an intranuclear microsporidium from salmonid fish. J Protozool |99|, 38:264-269.

33. Desportes-Livage I, Chilmonczyk S, Hedrick R, Ombrouck C, Monge D, Maiga I, Gentilini M: Comparative development of two microsporidian species: Enterocytozoon bieneusi and Enterocytozoon salmonis, reported in AIDS patients and salmonid fish, respectively. J Euk Microbiol 1996, 43:49-60.

34. Lom J, Dyková I: Ultrastructure of Nucleospora secunda n. sp. (Microsporidia), parasite of enterocytes of Nothobranchius rubripinnis. Eur J Protistol 2002, 38: 19-27.

35. Spurr AR: A low-viscosity epoxy resin embedding medium for electron microscopy. JUltrastruct Res 1963, 26:31-43.

36. Thompson JD, Gibson TJ, Plewniak F, Jeanmougin F, Higgins DG: The CLUSTAL-X windows interface: flexible strategies for multiple sequence alignment aided by quality analysis tools. Nucl Acids Res 1997, 24:4876-4882.

37. Saitou N, Nei M: The Neighbour-joining method: A new method for reconstructing phylogenetic trees. Mol Biol Evol 1987, 4:406-425.

38. Swofford DL: PAUP*. Phylogenetic analysis using parsimony (*and other methods), v. $\mathbf{4 . 0}$ betal 0. Sinauer Associates, Sunderland, MA, USA; 2002.

39. Bresciani J: The fine ultrastructure of the integument of freeliving and parasitic copepods: a review. Acta Zool 1986, 67:125-145

40. Boxshall GA: Copepoda. In Microscopic anatomy of invertebrates: Crustacea Volume 9. Edited by: Harrison FW, Humes AG. New York: Wiley-Liss; 1992:347-384

4I. Cali A, Owen RL: Intracellular development of Enterocytozoon, a unique microsporidian found in the intestine of AIDS patients. J Protozool 1990, 37:145-155.

42. Vossbrinck CR, Debrunner-Vossbrinck AB: Molecular phylogeny of the microsporidia: ecological, ultrastructural and taxonomic considerations. Folia Parasitol 2005, 52: |3|-| 42.

43. Takvorian PM, Cali A: Appendages associated with Glugea stephani, a microsporidian found in flounder. J Protozool 1983, 30:25I-256.

44. Mitchell MJ, Cali A: Ultrastructural study of the development of Vairimorpha necatrix (Kramer, 1965) (Protozoa, Microsporidia) in larvae of the corn earworm, Heliothis zea (Boddie) (Lepidoptera, Noctuidae) with emphasis on sporogony. J Euk Microbiol 1993, 40:70I-7IO.

45. Cali A, Takvorian PM: Developmental morphology and life cycles of the microsporidia. In The microsporidia and microsporidiosis Edited by: Wittner M, Weiss LM. Washington: ASM Press; 1999:85-128. 
46. Ghadially FN: Ultrastructural pathology of the cell and matrix Volume I. Fourth edition. Oxford: Butterworth Press; 1997.

47. Eaton WD, Kent ML: A retrovirus in chinook salmon (Onchorhynchus tshawytscha) with plasmacytoid leukemia and evidence for etiology of the disease. Cancer Res 1992, 52:6496-6500.

48. Kent ML, Dawe SC: Further evidence for a viral etiology in plasmacytoid leukemia of chinook salmon Oncorhynchus tshawytscha. Dis Aquat Org 1993, I5: I I5-121.

49. Kotler DP, Orenstein JM: Clinical syndromes associated with microsporidiosis. In The microsporidia and microsporidiosis Edited by: Wittner M, Weiss LM. Washington: ASM Press; 1999:258-292.

Publish with Bio Med Central and every scientist can read your work free of charge

"BioMed Central will be the most significant development for disseminating the results of biomedical research in our lifetime. "

Sir Paul Nurse, Cancer Research UK

Your research papers will be:

- available free of charge to the entire biomedical community

- peer reviewed and published immediately upon acceptance

- cited in PubMed and archived on PubMed Central

- yours - you keep the copyright

Submit your manuscript here:

http://www.biomedcentral.com/info/publishing_adv.asp
BioMedcentral 